\title{
THE ROLE OF ZAKAT IN BUSINESS DEVELOPMENT OF SMES (STUDY ON BAZNAS SEMARANG, CENTRAL JAVA, INDONESIA)
}

\author{
Fatmasari Sukesti ${ }^{1 *}$, Mamdukh Budiman $^{2 *}$
}

\section{* Affiliation:}

${ }^{1}$ University of

Muhammadiyah

Semarang, Jalan

Kedungmundu 18

Semarang, Indonesia

Email:

fatmasaris@yahoo.com

\begin{abstract}
Poverty in developing countries including Indonesia still an unresolved phenomenon. The distribution of assistance through productive zakat is believed to be one of the solutions in alleviating poverty by giving zakat which used for working capital of small and medium-sized businesses. This study examined the role of productive zakat given to SMEs in the city of Semarang through the Badan Amil Zakat Nasional (BAZNAS) Semarang. The result showed that productive zakat had significant positive effect on business development of SMEs. The value of $\mathrm{R}$-squared generated 0.767 that mean variable dependent can be explained by four independent as much $76 \%$ and the $24 \%$ with other variable outside research.

keywords : Productive zakat, BAZNAS, SMEs
\end{abstract}

\section{INTRODUCTION}

Zakat is the third pillar of Islam after the creed and prayer. Put out zakat is an obligation for Muslims who have fulfilled the requirements of income and calculated once a year. The tithe order is clearly stated in the Al Quran (At-Taubah, 103). In the Qur'an, Allah said:

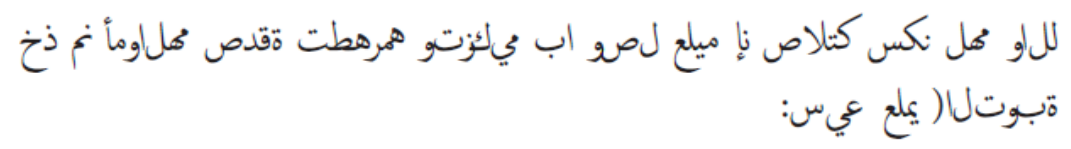

That meaning : Take charity from some of their assets, with that charity you cleanse and purify them and pray for them. In fact your prayers (become) peace of mind for them. And Allah is the Hearing, the Knower (At-Taubah: 103).

Expenditures zakat from the rich people to be given to the people who are meet the criteria set out in Islam. There are eight categories of recipients of zakat, there are fakir, poor, amil zakat, mualaf, riqab (slaves), gharim (people are in debt), sabillilah,and ibnu sabil. In the economic field, the distribution of zakat can play a role in helping the economy of a group of needy and poor people so that the basic necessities of life can be fulfilled and can play a role in their lives, carrying out their obligations to Allah. Zakat could made people feel that they are part of the community. 
Zakat distribution not only develops to consumptive zakat, but also the provision of productive zakat so zakat can play a role as a potential source of funds to alleviate poverty. (Mustarin, 2017) said that the productive zakat funds used to empower the poor will be productively and became the transformation from mustahiq to muzakki so that it can help and benefit other mustahiq.

The existence of zakat is regulated in Peraturan Pemerintah Republik Indonesia Number 14 of 2014 concerning the implementation of law number 23 of 2011 for the management of zakat which aims to improve the effectiveness and efficiency of services in the management of zakat and increase the benefits of zakat to realize community welfare and poverty reduction through BAZNAS in charge to manage zakat. The Law on zakat management in Indonesia number 23 of 2011 has regulated the use of zakat for productive purposes. The utilization of the results of collecting zakat based on the priority scale of mustahiq needs and can be used for productive businesses. The provision of working capital for Small and Medium Enterprises (SMEs) becomes part of the distribution of productive zakat.

The provision of productive zakat is believed to be able to contribute in promoting social justice, human development and being able to alleviate poverty. Indonesia has a high potential of zakat, infaq and waqf because it has the largest Muslim population in the world. However, the existing potential cannot yet be managed and utilized maximally so that it does not have a significant impact on the resolution of existing problems. The institution of Amil Zakat as the professionalism and modern management, will be able to deliver zakat to be part of the problem solver, especially the problem of poverty alleviation which continues to develop. Ahmad, Othman, \& Salleh (2015) said the main aims of zakat to improve of sosio economi status of the recipients and the nations as a whole.

According Atabik (2015), the role of zakat in poverty alleviation is the concern of the aghniya 'to pay zakat and gives sadaqah. In the economic context, both are forms of distribution of wealth among fellow humans. Moreover, the role of zakat is not only limited to poverty alleviation, but also aims to overcome other social problems. If all rich people in various Islamic countries want to issue their zakat proportionally and be distributed fairly and inevitably poverty will become lost (Qaradhawi, 2005).

Productive zakat can be used as a means to improve the welfare of the poor through business capital loans in accordance with sharia principles, provision of business tools, fish breeding, agricultural nurseries, livestock and so forth as well as the use of zakat for the poor through skills training and product development so that later the community poor have provisions in the form of experiences that can be used to change their lives for the better. This is because the poor are part of the recipients of zakat.

Rohman, Anwar, \& Subadriyah (2017) have proved that the provision of productive zakat can increase public trust in the welfare of recipients of zakat so as to provide opportunities for considerable potential for the acquisition of zakat in the SME sector. The muzaqi perception that distributes zakat directly does not significantly affect the level of welfare mustahiq. While the distribution of zakat which is productive, has a significant influence. The results of this study support prior research conducted by Burhanudin (2014), Widiastuti \& Rosyidi (2015) and Alaydrus (2016) which proved that the amount of ZIS business capital assistance and the 
number of productive ZIS had a very significant influence on the development of mustahiq micro-businesses. Different research results from Miranda (2018) found that ZIS assistance in the form of business capital did not affect welfare and mustahiq business income.

Based on the explanation above there are differences in the results of research on the role of productive zakat in improved the welfare of mustahiq and the unresolved phenomenon of poverty, That are the reason for re-examine the role of zakat in an effort to help alleviate poverty with the title "THE ROLE OF ZAKAT ON BUSINESS DEVELOPMENT OF SMEs "(Study on BAZNAS Semarang, Central Java, Indonesia).

\section{LITERATURE REVIEW}

\section{Badan Amil Zakat nasional (BAZnAS) Semarang}

Badan Amil Zakat Nasional (BAZNAS) Semarang according to mandate UndangUndang Nomor 23 in 201, concerning zakat management is a non-structural government institution that is tasked with managing zakat, infaq and alms. BAZNAS Semarang as zakat management institution always tries to apply the concept of professional, trustworthy, transparent and accountable into the standard operating procedures of zakat management institutions. BAZNAS Semarang was formed to achieve usability, effectiveness and accountability in the management of zakat, infaq and shadaqah (ZIS) funds so as to increase the participation of Muslims in Semarang in the framework of full human development with the collection and management of zakat, infaq and shadaqah (ZIS ) in assisting the government in alleviating poverty in Semarang City. Badan Amil Zakat Nasional (BAZNAS) Semarang was formerly called Badan Amil Zakat (BAZ) Semarang in accordance with Undang Undang number 38 of 1999 concerning the management of zakat. Badan Amil Zakat (BAZ) of Semarang was established on Friday June 13, 2003 in accordance with Surat Keputusan Walikota Number 451.1.05.159 dated June 13, 2003 concerning the establishment of Badan Amil Zakat Semarang (BAZ).

BAZNAS as a zakat management organization has quality objectives to optimizing the collection of Zakat Infak Shadaqah (ZIS) from ministries, institutions, government agencies, goverment companies, private and public companies according to the laws and regulations. ZIS distribution and utilization programs by involving various related institutions to improve the welfare of mustahiq. Then strengthen cooperation with Islamic community organizations and other relevant parties to optimize socialization and education of ZIS and da'wah and building a strong BAZNAS management system through the implementation of standard operating standards and the implementation of online systems based on information and communication technology on all aspects of work. Last, BAZNAS building a transparent and accountable financial management system in accordance with sharia and statement of financial accounting standards number 109 and develop a fair, transparent and empowering human resource management system.

BAZNAS have quality policies outlined in the following steps to increase the awareness of zakat according to sharia and legislation to improve the welfare of mustahiq and providing the best service for muzakki and mustahiq. The other policies are creating a zakat utilization program in accordance with sharia in a planned, measurable and sustainable manner in improving 
the welfare of mustahiq, then foster and develop trustworthy, integrity and competent amil that can foster an Islamic work culture and develop the best models of zakat management that can be used as a reference for the world.

One of the BAZNAS programs in SMEs development is the Semarang Makmur program, which includes Bina Mitra Mandiri, a productive economic empowerment program that is managed systematically, intensively and continuously. Mustahiq in this program are given revolving funds, skills, business insights and business assistance, education in savings, potential exploration, moral development and character to be empowered and encouraged to be more independent.

Zakat that has been distributed to the mustahiq under supervision in the used of funds. Supervision of zakat management is a necessity, so that with supervision it expected that zakat runs in accordance with the objectives of zakat management. The process of supervising the management of zakat as follows formed a supervisory team involving employees in the Semarang City Ministry of Religion and local community leaders or ulama, then the supervisor called the zakat managers to be held accountable in the form of zakat management reports. In addition, supervisors go directly to monitor the zakat managers to find out whether they are running properly in managing zakat assets.

Granting of zakat believed to be able to contribute in promoting social justice, human development and being able to alleviate poverty. Indonesia has the potential of zakat, infaq and waqf which are quite high. However, the existing potential cannot yet be managed and utilized maximally so that it does not have a significant impact on the resolution of existing problems. According to Alim (2015) the regulation of zakat in Indonesia decides that zakat can be used for productive purposes to help the poor and improve the quality of society. The establishment of BAZNAS is intended as a management institution of zakat with modern management that can deliver zakat to be part of the problem solver that continues to develop national conditions. BAZNAS strives to develop itself into a trusted Zakat Institution through a work culture that is trustworthy, professional and transparent,

\section{Productive Zakat in the Islam Perspective}

Zakat is a basic word that means blessing, growing, clean, good, and increasing. Whereas in terms of zakat is the ownership of property that is devoted to the recipient with certain conditions. The productive word is derived from English, which is "productive" which means to produce or provide many results. So, it can be concluded that the notion of productive zakat is the provision, management and distribution of zakat funds that are productive, which provide benefits and have long-term effects for the recipients of zakat. The distribution of productive zakat funds is carried out in order to realize one of the aims of zakat, namely to alleviate the poverty of the people in a gradual and continuous manner. Beik (2009) proved that zakat can reduce the number and percentage of poor families and reduce the severity of poverty.

According Qaradhawi (2005), provision productive zakat is permissible even highly recommended if it is related to the current situation and condition of the Indonesian state. Moreover, zakat has a very important role and function in the economic, social and educational fields, which currently needs attention from all levels of the Indonesian people. Producing 
or cultivating zakat funds in principle does not conflict with the principles of Islamic law. Productive zakat will make the earth's treasures revolve among all humans, not only for some people, especially among rich people, as the word of Allah:

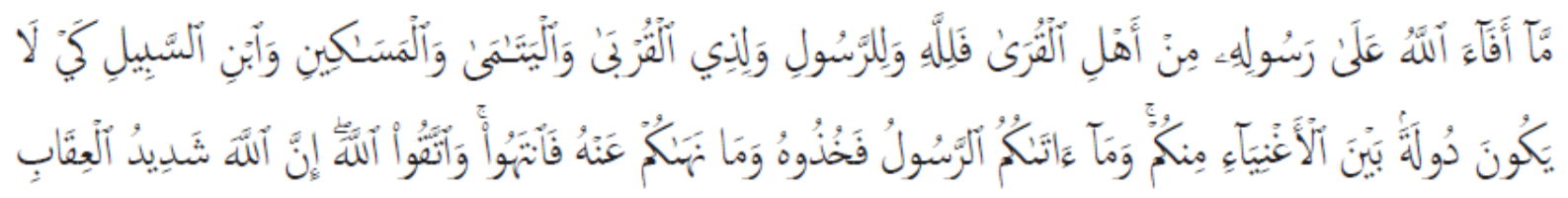

Meaning:

«What are the spoils (fai-i) given by Allah to His Messenger (from possessions) that come from the inhabitants of the cities and are for Allah, for the Apostles, the relatives, the orphans, the poor and people who are on the way, so that the property does not circulate among the rich people among you ... «

Productive zakat become more consideration because if zakat all given in a consumptive way, it will make the recipient of zakat become lazy and always hope for the generosity of the rich, familiarize them with the hands below, ask and wait for mercy. Though this is very unpopular in the teachings of Islam. Islam strongly recommends that its people strive to carry out religious teachings well, including paying zakat, infaq, and alms and other services which in practice require material or financial costs and abilities. The virtues and importance of working and trying as a way to get sustenance are also exemplified by the prophets. Prophet David, the ironworker of weapons, the prophet Noah, a carpenter, prophet Idris, a tailor, Moses the shepherd, and the prophet Muhammad SAW, a shepherd. So it can be said that working and trying as the only main way to get sustenance from Allah SWT. By earning productive zakat funds, it is hoped that the business will become more developed and advanced and change the life of the recipient of zakat to be the provider of charity.

\section{Development of Small Medium Entreprises (SMEs)}

Small and Medium Enterprises (SMEs) according to Undang Undang number 20 of 2008 concerning SMEs (Small and Medium Enterprises) are productive businesses owned by individuals and / or individual business entities that meet the criteria of Small and Medium Enterprises as regulated in this Law. The criteria for distinguishing whether a business is a type of micro, small or medium business is usually based on the criteria of the number of assets owned, turnover generated or can also be based on the amount of labor owned. Table 2.1. are the criteria for SMEs based on the number of assets and business turnover. 
Table 2.1.

SMEs Criteria

\begin{tabular}{|l|l|l|}
\hline \multicolumn{1}{|c|}{ Size } & \multicolumn{1}{|c|}{ Asset } & \multicolumn{1}{c|}{ Turnover } \\
\hline Small & $>\operatorname{Rp~50~million~}-\mathrm{Rp} \mathrm{500} \mathrm{million}$ & $>\mathrm{Rp} \mathrm{300} \mathrm{million}-\mathrm{Rp} \mathrm{2,5} \mathrm{billion}$ \\
\hline Medium & $>\operatorname{Rp~500~million~}-\mathrm{Rp} \mathrm{10} \mathrm{billion}$ & $>\mathrm{Rp} \mathrm{2,5} \mathrm{billion-} \mathrm{Rp} \mathrm{50} \mathrm{billion}$ \\
\hline Large & $>\operatorname{Rp~10~billion~}$ & $>\mathrm{Rp} \mathrm{50} \mathrm{billion}$ \\
\hline
\end{tabular}

SMEs are one of the pillars of the Indonesia economy. Indonesia, Central Bureau of Statistics presented that more than 50 million business units are in this sector. So, it can be said that most of the businesses in Indonesia are actually Micro and Small and Medium Enterprises. Providing financial assistance from productive zakat is a way to encourage the progress of SMEs, so developing SMEs can expand employment opportunities and reduce unemployment. SME development can strengthen and improve the economy in Indonesia.

\section{METHODOLOGY}

\section{Sample and Data}

The research used secondary data obtained from BAZNAS Semarang. The data collected are information on the amount of productive zakat distributed to SMEs, the name mustahiq who receives productive zakat, the age of recipients of zakat, the sex of recipients of productive zakat, data on business development, and the briefing given. The sample are mustahiq recipients of productive zakat from BAZNAS in 2016-2017 in accordance with the specified criteria of 70 people.

\section{Analysis Method}

This study analyzed using multiple regression methods with the SPSS statistical tool. This research examined the effect of productive zakat given to SMEs by using the regression equation:

$Y=\beta_{0}+\beta_{1} X 1+\beta_{2} X 2+\beta_{3} X 3+\beta_{4} X 4+e \ldots$

$\mathrm{Y}=$ Business Development of Mustahiq

$\mathrm{X} 1=$ Zakat

$\mathrm{X} 2=$ Briefing

$\mathrm{X} 3=$ Age

$\mathrm{X} 4$ = Gender

$\beta_{0 .} \beta_{4}=$ constanta

$\mathrm{e}=$ error

Measurement of variable $\mathrm{Y}$ uses data on the average business development per month given to Mustahiq from the zakat that has been received. X1 = Amount of Zakat given. X2 is the Briefing by Baznas to mustahiq, X3 is the age of the recipient of zakat, $\mathrm{X} 4$ is the sex of the recipient of zakat measured using a dummy variable, if a man sells 1 if a woman is 0 . 


\section{RESULT AND ANALYSIS}

\section{Descriptive Statistic}

The results of testing variables are descriptively explained in table 4.1. below

Table 4.1.

\section{Descriptive Statistics}

\begin{tabular}{|l|r|r|r|r|r|}
\hline & \multicolumn{1}{|c|}{$N$} & Minimum & \multicolumn{1}{c|}{ Maximum } & \multicolumn{1}{c|}{ Mean } & Std. Deviation \\
\hline Business Development & 70 & 100000.00 & 675550.00 & 336131.4286 & $1.50328 \mathrm{E} 5$ \\
$(0)$ & 70 & 500000.00 & 2500000.00 & $1.3536 \mathrm{E} 6$ & $6.21902 \mathrm{E} 5$ \\
Zakat $(\alpha 1)$ & 70 & 23.00 & 46.00 & 33.6000 & 5.96706 \\
Age $(\times 2)$ & 70 & 1.00 & 4.00 & 2.3000 & .99782 \\
Briefing $(\times 3)$ & 70 & .00 & 1.00 & .4429 & .50031 \\
Gender $(\alpha 4)$ & 70 & & & & \\
Valid $N$ (listwise) & & & & \\
\hline
\end{tabular}

Table 4.1. showed that the SMEs business development variable (Y) a minimum of Rp. 100,000, and a maximum of Rp. 675,550. That mean the business of SMEs develops between $20 \%-50 \%$ of business capital provided through productive zakat. Variable zakat (X1) is the amount of zakat received minimum Rp. 500,000, and a maximum of Rp. 2,500,000,- in 20162017, this amount is in accordance with BAZNAS policy in providing productive zakat is Rp. 500,000 , and will be given again if the business increases as big as the multiples. The age of productive zakat recipients (X2) are between 23 years and 43 years. Briefing (X3) conducted by BAZNAS to recipients of the minimum charity is done once and a maximum of 4 times in the year of research observations. Zakat recipients (X4) consist of 70 people who are male as many as 31 people and female 39 people.

\section{Result Analysis regression linear}

Table 4.2.

\section{Coefficients $^{a}$}

\begin{tabular}{|c|c|c|c|c|c|c|}
\hline \multirow{2}{*}{\multicolumn{2}{|c|}{ Model }} & \multicolumn{2}{|c|}{ Unstandardized Coefficients } & \multirow{2}{*}{$\begin{array}{c}\begin{array}{c}\text { Standardized } \\
\text { Coefficients }\end{array} \\
\text { Beta }\end{array}$} & \multirow[b]{2}{*}{$t$} & \multirow[b]{2}{*}{ Sig. } \\
\hline & & $\mathrm{B}$ & Std. Error & & & \\
\hline \multirow[t]{5}{*}{1} & (Constant) & 12249.153 & 55671.775 & & .220 & .827 \\
\hline & Zakat $(\times 1)$ & .267 & .032 & 1.104 & 8.446 & .000 \\
\hline & Age $(\times 2)$ & 1951.526 & 1568.879 & .077 & 1.244 & .218 \\
\hline & Briefing $(\times 3)$ & -42185.936 & 19628.960 & -.280 & -2.149 & .035 \\
\hline & Gender $(\times 4)$ & -13118.202 & 18556.258 & -.044 & -.707 & .482 \\
\hline
\end{tabular}

a. Dependent Variable: Business Development( $(9)$

Table 4.2. above showed the results of statistical analysis carried out for multiple linear regression research models and $t$ statistic test showed that the variable of giving productive zakat has a beta coefficient of 0.267 and has a significant positive effect on SMEs business development. The results showed that the greater the productive zakat received mustahiq, 
the mustahiq business would develop. This study supports the result of previous studies from Burhanudin ( 2014).

Table 4.3.

Model Summary

\begin{tabular}{|l|l|r|r|r|}
\hline Model & $\mathrm{R}$ & R Square & $\begin{array}{c}\text { Adjusted R } \\
\text { Square }\end{array}$ & $\begin{array}{c}\text { Std. Error of } \\
\text { the Estimate }\end{array}$ \\
\hline 1 & $.876^{\mathrm{a}}$ & .767 & .752 & 74811.11931 \\
\hline
\end{tabular}

a. Predictors: (Constant), Gender ( $(4)$, Zakat $(\times 1)$, Age $(\times 2)$, Briefing ( $\times 3$ )

Table 4.3. above R2 showed that the dependent variable affected by $76 \%$ by the independent variable. While the remaining $24 \%$ influenced by other factors beyond the variables observed in this study.

\section{dIscussIon}

The result of the study proven that the provision of productive zakat had a positive and significant influence on the development of SME businesses. This study provide empirical evidence that productive zakat can bring change to mustahiq to improve growth, blessings and SMEs business development.

Distributing zakat as productive zakat to encourage SMEs to work optimally and obtain adequate results. The zakat management system through amil zakat believed to be able to reduce the poverty rate of the community significantly, compared to if zakat is directly given. With productive zakat mustahiq not only receives zakat just to make ends meet, but to improve welfare.

\section{REFERENCES}

Ahmad, R. A. R., Othman, A. M. A., \& Salleh, M. S. (2015). Assessing the Satisfaction Level of Zakat Recipients Towards Zakat Management. Procedia Economics and Finance, 31(15), 140-151. https://doi.org/10.1016/S2212-5671(15)01141-7

Alaydrus, M. Z. (2016). Pengaruh zakat produktif terhadap pertumbuhan usaha mikro dan kesejahteraan mustahik pada badan amil zakat kota pasuruan jawa timur. Universitas Airlangga Surabaya.

Alim, M. N. (2015). Utilization and Accounting of Zakat for Productive Purposes in Indonesia: A Review. Procedia - Social and Behavioral Sciences, 211(September), 232-236. https://doi.org/10.1016/j.sbspro.2015.11.028

Atabik, A. (2015). Peranan zakat dalam pengentasan kemiskinan. ZISWAF: Jurnal Zakat Dan Wakaf, 2(2), 339-361. 
Beik, irfan. (2009). Analisis Peran Zakat Dalam Mengurangi Kemiskinan: Studi

Kasus Dompet Dhuafa Republika. Zakat \& Empowering - Jurnal Pemikiran Dan Gagasan, 2(August), 45-53.

Burhanudin, M. (2014). Pengaruh Pengelolaan Zzakat Produktif Terhadap Perkembangan Usaha Masyarakat Mandiri Club Di PMA Al-Bunya Bogor. Jurnal Ekonomi Islam, 5(1), 88-129.

Miranda, G. E. (2018). Analisis Pengaruh Pendayagunaan Zakat Produktif Terhadap Perkembangan Usaha Mikro Mustahik (Studi kasus Baznas). Islamic University of Syarif Hidayatullah.

Mustarin, B. (2017). Urgensi pengelolaan zakat terhadap peningkatan perekonomian masyarakat. Jurisprudentie, 4(2), 83-95.

Qaradhawi, Y. (2005). Spektrum zakat dalam membangun ekonomi kerakyatan. (S. Narulita, Ed.). Jakarta: Zikrul Hakim.

Rohman, F., Anwar, A. Z., \& Subadriyah, S. (2017). Analisa Potensi Zakat UMKM Mebel Melalui BAZNAS untuk Peningkatan Kesejahteraan Masyarakat Jepara. Perisai : Islamic Banking and Finance Journal, 1(3), 21. https://doi.org/10.21070/perisai. v1i3.1068

Widiastuti, T., \& Rosyidi, S. (2015). Model Pendayagunaan Zakat Produktif Oleh Lembaga Zakat Dalam Meningkatkan Pendapatan Mustahiq. JEBIS, 1(1), 89-102. 